\title{
Genetic divergences between Spondias mombin (Anacardiaceae) genotypes found through morphological traits
}

\author{
Bruna Mezzalira da Silva ${ }^{1}$, Ana Aparecida Bandini Rossi ${ }^{1,2,3}$, \\ Juliana de Freitas Encinas Dardengo ${ }^{2}$, Poliana Vicente Tiago ${ }^{3}$, Greiciele Farias da Silveira ${ }^{1}$ \\ \& Sérgio Alessandro Machado Souza ${ }^{2,3}$ \\ 1. Genetics and Plant Breeding Major - Mato Grosso State University, Perimetral Rogério Silva, 78.580-000, Alta \\ Floresta, Mato Grosso, Brazil; bruna_mezzalira@hotmail.com, anabanrossi@gmail.com, \\ greicielefarias@hotmail.com \\ 2. Bionorte Post-Graduation Program, Perimetral Rogério Silva, 78.580-000, Alta Floresta, Mato Grosso, Brazil; \\ ju_kk@hotmail.com \\ 3. Biodiversity and Amazon Agroecosystems Major - Mato Grosso State University, Perimetral Rogério Silva, \\ 78.580-000, Alta Floresta, Mato Grosso, Brazil; polianavt29@hotmail.com, sergiobioufpel@yahoo.com.br
}

Received 06-IV-2017. Corrected 21-VII-2017. Accepted 23-VIII-2017.

\begin{abstract}
The species Spondias mombin, is native to the Amazonian region. Since these trees' cultivation is incipient, their exploitation is done through extraction techniques. The aim of the present study was to assess the genetic divergences between $S$. mombin genotypes and to quantify the relative contribution from 12 morphological traits of the species' fruits and seeds, as well as to collect data able to subsidize future research on the species conservation and domestication. 60 genotypes were assessed in total, and ten fruits of each genotype were analyzed. Eight descriptors were used for fruit characterization, namely: fruit mass, pulp weight, volume, length, width, thickness, total soluble solids content and hydrogenionic potential. The seed descriptors were mass, length, width and thickness. The data were assessed through the principal components and groupings by applying the UPGMA and Tocher methods. They were analyzed in the GENES software, based on the dissimilarity matrix (Euclidean distance average). The analysis applied to the principal components showed that the first three components explained $83 \%$ accumulated variation. The main traits contributing to the genotype discrimination were fruit width, fruit pulp weight, $\mathrm{pH}$, seed length and thickness, and the most responsive traits to $S$. mombin genotype selection. The features fruit mass, seed width, fruit thickness, fruit volume, fruit length, seed mass and total soluble solid content presented the smallest contribution to diversity. The grouping methods UPGMA and Tocher evidenced genetic divergence between the analyzed genotypes. Genotypes 37 and 41 were more divergent than the others, what makes them promising for crossings in future genetic enhancement programs focused on the species' domestication. Rev. Biol. Trop. 65 (4): 1337-1346. Epub 2017 December 01.
\end{abstract}

Key words: cajá, fruitful, Amazonian rainforest, genetic resource.

Brazil ranks third in fresh fruit production in the world, after China and India. However, the country ranks first in tropical fruits production (Ministério da Agricultura, Pecuária e Abastecimento, 2007). Currently, the international market increasingly demands fruits of new flavors and textures, and Brazil, due to its huge biodiversity and edaphoclimatic conditions, has the potential to provide such natural plant resources (Schwartz, Fachinello, Barbieri, \& Silva, 2010).

The genus Spondias holds native fruit species such as "umbutree" (S. tuberosa Arruda), "umbu-caja tree" (Spondias sp.) and "cajá tree" (S. mombin L.), which deserve special attention. Cajá tree has great socioeconomic importance in the Brazilian Northern and Northeastern regions, since it is one of the most 
appreciated native fruits commercialized in those places. The local population uses the cajá fruit to produce juice, nectar, ice cream, jelly, wine and liqueur, among others (Silva-Junior, Bezerra, Lederman, Alves, \& Neto, 2004).

Cajá fruit exploitation in Brazil is performed through extraction due to lack of technical domestication knowledge. Studies aiming at characterizing this genetic resource, and its sustainable use, are demanding. Accordingly, agribusiness activities remain fully dependent on the extraction production, which is seasonal and insufficient to the industrial production throughout the year (Martins \& Melo, 2006). Thus, the genetic enhancement applied to this fruit species seeks its domestication process and compliance to the consumer market demands, mainly to the quality of the fruit (Braga et al., 2006). However, the genetic variability of the material to be used in the genotype selection must be studied so that the plant breeding programs can be started.

Therefore, the genetic resources must be properly marked to enable promising genetic gains, so their use by farmers can be encouraged (Coelho, Coimbra, Souza, Bogo, \& Guidolin, 2007). Currently, the genotype characterization is based on inheritable and measurable morphological markers of easy visualization, which, at first, are expressed in all environments (IPGRI, 1996). Morphological descriptors are useful tools for genetic characterization and enhancement, because they are based on the phenotype, what makes the study easy and cheap (Vieira, 2007). According to Borém (2006), morphological descriptors play a fundamental role in the dissemination of the agronomic traits of new genetic material, and may decisively influence producers' choices. Besides, native species such as Cajá $[\leftarrow$ or cajá?] are losing their habitat due to intense forest fragmentation in the Amazonian region. Thus, genetic diversity preservation has been the focus of conservation programs concerning the preservation of genes of interest, because such preservation allows the maintenance of the species' variability at genetic level (Alves, Garcia, Cruz, \& Figueira, 2003).
The aim of the present study was to assess the genetic divergence between $S$. mombin genotypes and to quantify the relative contribution from 12 morphological traits of fruits and seeds, as well as to collect data able to support future research on this species' domestication.

\section{MATERIALS AND METHODS}

Study area and plant material: The fruit collection was carried out in three counties located in Northern Mato Grosso State: Alta Floresta $\left(09^{\circ} 52^{\prime} 32^{\prime \prime} \mathrm{S}-56^{\circ} 05^{\prime} 10^{\prime}\right.$ " W), Marcelândia ( $\left(11^{\circ} 05^{\prime} 22^{\prime \prime} \mathrm{S}-54^{\circ} 27^{\prime} 02^{\prime \prime} \mathrm{W}\right)$ and Nova Bandeirante $\left(09^{\circ} 48^{\prime} 50^{\prime \prime} \mathrm{S}-57^{\circ} 51^{\prime} 43^{\prime \prime}\right.$ W), in June 2014 (Fig. 1). Genotypes were sampled in different areas of Alta Floresta (individuals from AFL1 to AFL20), Marcelândia (individuals from MAR21 to MAR40), and Nova Bandeirante (individuals from NBA41 to NBA60) counties. In addition, 10 ripe fruits from each genotype were collected, thus totaling 600 fruits.

Each plant produces 60 fruits, on average. The cajá tree pollination is of the anemophilous type, based on the flowers' anatomical traits. However, this species flowers are devoid of attractive colors, nectar and of all kinds of possible attractive factors to pollinators (SilvaJunior et al., 2004).

Fruit morphological traits: A total of eight fruit traits were assessed. The fruit length (FL), width (FW), and thickness (FT) were assessed using a digital pachymeter (Starret 799). The fruit mass (FM) was measured in a ' $0.00001 \mathrm{c}$ ' $\mathrm{g}$ scale $(0.01 \mathrm{~mm}$ accuracy) and the fruit pulp mass (FPM) was measured by subtracting the seed mass from the fruit mass (FM - SM = FPM). The total soluble solid content (TSS) was directly red in the manual refractometer (Mettler $30 \mathrm{PX}$ ); data were corrected through temperature. The fruit volume (FV) resulted from the water volume displaced after fruit immersion in a $100 \mathrm{~mL}$ beaker. The fruit pulp was extracted, homogenized and assessed in a potentiometer (Labmeter, $\mathrm{PH} 2$ ) -calibrated at $25^{\circ} \mathrm{C}$ - to find the $\mathrm{pH}$ values. 


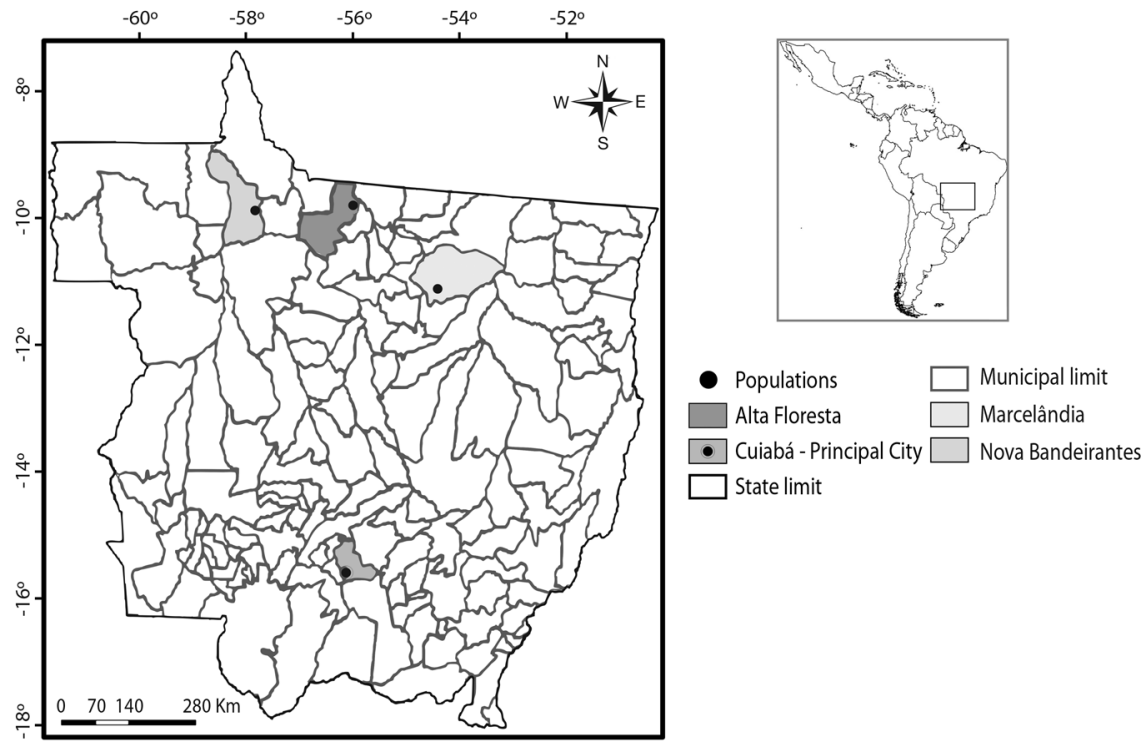

Fig. 1. Alta Floresta, Marcelândia and Nova Bandeirantes counties located in Southern Amazon, Northern Mato Grosso State, Brazil.

Seed morphological traits: Four traits were used to assess the seeds, namely: seed length (SL), width (SW), and thickness (ST), which were measured in a digital pachymeter (Starret 799; at $0.01 \mathrm{~mm}$ accuracy). The seed mass (SM) was measured in a '0.00001' $\mathrm{g}$ precision scale.

The genotype genetic divergence estimates were found through the standardized mean Euclidean distance method. The generated dissimilarity matrix was used in the grouping analysis, which was performed through the hierarchical UPGMA (Sneath \& Sokal, 1973) and the non-hierarchical Tocher optimization methods (Rao, 1952). The grouping validation through the UPGMA method was determined by the cophenetic correlation coefficient (CCC) (Sokal \& Rohlf, 1962). The principal component analysis was performed to define the traits that could contribute the most to diversity studies.

The used variables disposal criterion was based on the recommendations by Jolliffe (1972), who suggests that the number of discarded variables should be equal to the number of principal components presenting variance (eigenvalue) lower than 0.7. Khattree and Naik (2000) stated that the variable presenting the highest absolute coefficient value in the principal component -with the lowest eigenvalue (smallest variance)- should be less important to explain the total variance; therefore, such variable would be the one to be discarded. Thus, the discarding process consisted of taking the component corresponding to the lowest eigenvalue into account and of rejecting the variable associated with the highest weight (in absolute value); then, the following lower component has to be assessed. The process must go on until the last component -associated with eigenvalue lower than 0.7- is taken into consideration. Such protocol is followed because the variables highly correlated with the major components -presenting the lowest variancesshow virtually insignificant variations.

The data set of each discard was reviewed in order to identify the new highest weight value in the last principal component. The elimination of a trait implies new weight coefficient values to the eigenvectors. It changes the contribution from each trait to the component, so it is worth re-analyzing the set of remaining 
descriptors. Accordingly, a new dissimilarity array was generated after the discard, in order to investigate possible distortions shown through the Tocher method in the groups (Rao, 1952). The GENES software was used in all statistical analyses (Cruz, 2008).

\section{RESULTS}

The descriptive analysis showed genetic divergence among the 60 assessed $S$. mombin genotypes. The variations in the 12 assessed traits were expressed through the magnitude of the amplitude values (Table 1). The morphological assessment applied to the traits was the instrument used to select the agronomic traits, i.e., the variations indicated the likelihood of genetic enhancement gains.

The assessed S. mombin fruits presented the following dimensions: $21.11 \mathrm{~mm}$ to 44.66 $\mathrm{mm}$ long, $31.85 \mathrm{~mm}$, on average; width ranging from $13.08 \mathrm{~mm}$ to $34.97 \mathrm{~mm}, 20.55 \mathrm{~mm}$, on average; fruit thickness between $14.45 \mathrm{~mm}$ and $29.51 \mathrm{~mm}, 21.36 \mathrm{~mm}$, on average; mean fruit weight $8.69 \mathrm{~g}$. The average values for fruit volume, pulp mass, total soluble solid content and $\mathrm{pH}$ variables showed values $9.95 \mathrm{ml} / 6.07$ g / $14.29^{\circ}$ Brix and 3.86, respectively (Table 1).
Four distinct groups were defined after the UPGMA method and the 12 quantitative traits were applied to the $60 \mathrm{~S}$. mombin genotypes (Fig. 2). The MAR32; MAR33; MAR31; MAR35 and MAR40 genotypes were put into group I, which comprised Marcelândia individuals, only. Group II showed the largest number of genotypes (63\%) and was composed of individuals from three locations: Alta Floresta (15 individuals), Marcelândia (09 individuals) and Nova Bandeirante (14 individuals). Group III held genotypes from Alta Floresta and Nova Bandeirante, namely: AFL4, AFL5, AFL7, NBA59, NBA60, NBA57, and AFL3. Group IV was the most isolated one and was mostly composed of Marcelândia genotypes (MAR21, MAR34, MAR39, MAR22, MAR38, MAR37, AFL15 and NBA 58) (Fig. 2).

The genetic dissimilarities among the 60 S. mombin genotypes varied from 0.753 to 0.045 . The lowest dissimilarity degree happened between genotypes MAR32 and MAR33 (0.045), whereas the most distant genotypes (maximum dissimilarity) were between AFL4 and MAR38 (0.753).

The Tocher optimization method enabled forming ten groups as follows: group I, formed by Marcelândia genotypes, only (MAR32,

TABLE 1

Descriptive analysis showing the overall averages, standard deviation (SD), minimum, maximum and the range of 12 traits assessed in $60 \mathrm{~S}$. mombin genotypes

\begin{tabular}{lccccc}
\multicolumn{1}{c}{ Variables } & Mean & SD & Minimum & Maximum & Ampleness \\
FL $(\mathrm{mm})$ & 31.85 & 4.10 & 21.11 & 44.66 & 23.55 \\
FW $(\mathrm{mm})$ & 20.55 & 2.88 & 13.08 & 34.97 & 21.89 \\
FT $(\mathrm{mm})$ & 21.36 & 2.76 & 14.45 & 29.51 & 15.06 \\
FV $(\mathrm{ml})$ & 9.95 & 3.42 & 2.00 & 21.00 & 19.00 \\
FWE $(\mathrm{g})$ & 8.69 & 3.05 & 2.60 & 18.63 & 16.03 \\
FPW $(\mathrm{g})$ & 6.07 & 2.51 & 0.15 & 15.27 & 15.12 \\
TSS & 14.29 & 2.81 & 5.00 & 22.00 & 17.00 \\
pH & 3.86 & 0.17 & 3.42 & 4.30 & 0.88 \\
SW $(\mathrm{g})$ & 2.62 & 1.17 & 0.67 & 6.29 & 5.62 \\
SL $(\mathrm{mm})$ & 26.52 & 3.60 & 13.40 & 40.03 & 26.63 \\
SWE $(\mathrm{mm})$ & 14.15 & 2.17 & 7.12 & 22.25 & 15.13 \\
ST $(\mathrm{mm})$ & 15.13 & 2.36 & 8.62 & 33.61 & 24.99 \\
\hline
\end{tabular}

FL: Fruit length (mm), FW: fruit width (mm), FT: fruit thickness (mm), FV: fruit volume (ml), FWE: fruit weight (g), FPW: fruit pulp weight (g), TSS: total soluble solids (Brix), pH: hydrogen potential, SWE: seed weight (g), SL: seed length (mm), SW: seed width $(\mathrm{mm})$ and ST; seed thickness $(\mathrm{mm})$. 


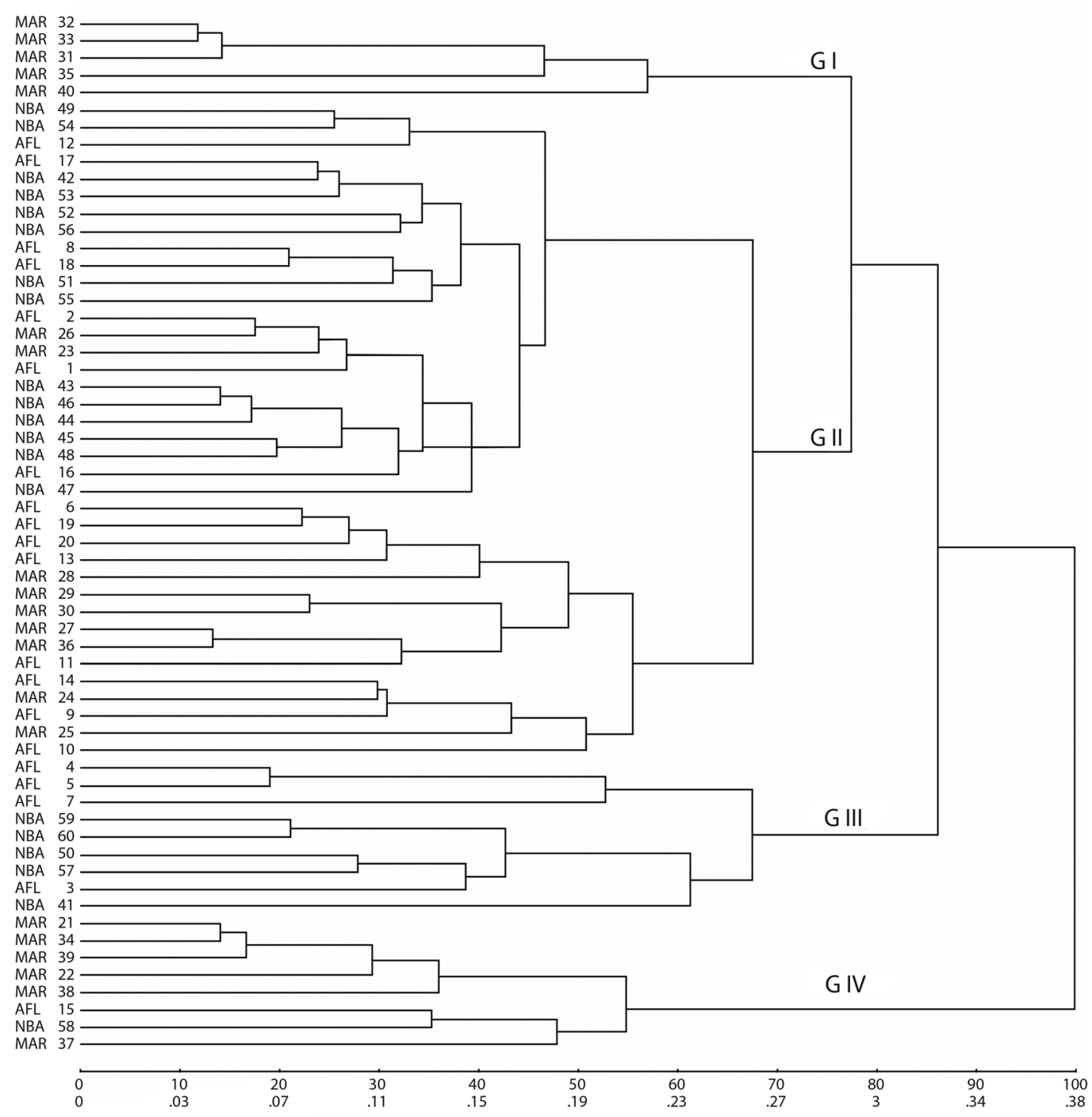

Fig. 2. Analysis of the $60 \mathrm{~S}$. mombin genotypes found through the UPGMA method and through the use of mean Euclidean distance as a genetic distance measure. Cophenetic coefficient correlation $(\mathrm{CCC})=0.6824$.

MAR33, MAR31 and MAR35); group II, composed of 29 genotypes, $48 \%$ of the assessed individuals; group III, composed of ten genotypes; group IV, composed of AFL4, AFL5 and AFL 7; group V, formed by three new genotypes from Bandeirante; group VI, composed of five genotypes; group VII, composed of individuals AF10, MAR25 and MAR24; and groups VIII, IX and X, formed by genotypes MAR40 NBR41 and MAR37, respectively (Table 2).
The principal component analysis showed that the first three components represented 83.6 $\%$ of the total variation, as well as that the first component explained $58.9 \%$ of the total variation; and the second one explained $74.9 \%$ of it (Table 3).

The eigenvalue and variance rate of 8 of the 12 principal components, presented variances lower than 0.7 (eigenvalue lower than 0.7). According to the criterion by Jolliffe 
TABLE 2

Grouping of the $60 \mathrm{~S}$. mombin genotypes through Tocher grouping method using the mean Euclidean distance as a genetic distance measure, this was based on 12 morphological traits

\begin{tabular}{cl} 
Groups & \multicolumn{1}{c}{ Genotypes } \\
I & MAR32 MAR33 MAR31 MAR35 \\
II & MAR27 MAR36 AFL11 AFL6 MAR28 AFL9 AFL19 AFL20 AFL13 NBA47 AFL16 MAR30 NBA50 \\
& MAR29 AFL3 AFL2 AFL14 MAR26 AFL1 NBA44 NBA46 NBA48 NBA43 NBA45 MAR23 AFL17 \\
& AFL18 AFL8 NBA42 \\
III & MAR21 MAR34 MAR39 MAR22 MAR38 NBA58 NBA52 NBA56 AFL15 NBA51 \\
IV & AFL4 AFL5 AFL7 \\
V & NBA59 NBA60 NBA57 \\
VI & NBA49 NBA54 AFL12 NBA53 NBA55 \\
VII & AFL10 MAR25 MAR24 \\
VII & MAR40 \\
IX & NBA41 \\
X & MAR37 \\
\hline
\end{tabular}

TABLE 3

Estimates of eigenvalues associated with the principal components and their relative (Root \%) and cumulative (\%) importance for the 12 morphological traits of $S$. mombin

\begin{tabular}{lccc}
$\mathrm{CP}^{1}$ & Eigenvalue & Relative importance (\%) & (\%) Accumulated \\
$\mathrm{CP}_{1}$ & 7.07 & 58.90 & 58.90 \\
$\mathrm{CP}_{2}$ & 1.92 & 16.03 & 74.93 \\
$\mathrm{CP}_{3}$ & 1.04 & 8.70 & 83.63 \\
$\mathrm{CP}_{4}$ & 0.83 & 6.88 & 90.51 \\
$\mathrm{CP}_{5}$ & 0.60 & 5.03 & 95.54 \\
$\mathrm{CP}_{6}$ & 0.34 & 2.86 & 98.40 \\
$\mathrm{CP}_{7}$ & 0.09 & 0.76 & 99.16 \\
$\mathrm{CP}_{8}$ & 0.04 & 0.33 & 99.50 \\
$\mathrm{CP}_{9}$ & 0.03 & 0.24 & 99.74 \\
$\mathrm{CP}_{10}$ & 0.02 & 0.15 & 99.89 \\
$\mathrm{CP}_{11}$ & 0.01 & 0.11 & 100.00 \\
$\mathrm{CP}_{12}$ & 0.00 & 0.00 & 100.00 \\
\hline
\end{tabular}

${ }^{1}$ Each principal component is a linear combination between the eighteen standardized variables.

(1972), the low eigenvalue principal components are those able to be discarded. Only the first four components fitting the herein adopted selection criterion were kept in the experiment, because their eigenvalues exceeded 0.7 and explained $90.51 \%$ of the total variation.

The seven variables presenting the highest weighting absolute coefficient value in the last principal component were liable to discard (Table 4). The variables showing the possibility to be discarded (Table 4), that were less important to explain the total variation in the present study were: fruit mass, seed width, fruit thickness, fruit volume, fruit length, seed mass, and total soluble solid contents. The lower the eigenvalue of a principal component is, the higher its weight and less its importance. Thus, the important variable in the principal component shall represent low significance in the data set. Although the variable 'fruit mass' 
TABLE 4

Set of eigenvectors (weighting) explained by the principal components (PCi) of the 12 variables in S. mombin

\begin{tabular}{ccccccccccccc} 
& \multicolumn{1}{c}{ Associated eigenvector elements } \\
$\mathrm{PC}_{\mathrm{i}}$ & $\mathrm{FL}$ & $\mathrm{FW}$ & $\mathrm{FT}$ & $\mathrm{LV}$ & $\mathrm{WEF}$ & $\mathrm{FPW}$ & $\mathrm{TSS}$ & $\mathrm{pH}$ & $\mathrm{SWE}$ & $\mathrm{SL}$ & $\mathrm{SW}$ & $\mathrm{ST}$ \\
$\mathrm{PC}_{1}$ & 0.31 & 0.34 & 0.35 & 0.34 & 0.36 & 0.30 & -0.22 & 0.11 & 0.29 & 0.27 & 0.26 & 0.24 \\
$\mathrm{PC}_{2}$ & -0.33 & 0.04 & 0.00 & -0.23 & -0.20 & -0.39 & -0.21 & 0.12 & 0.29 & -0.13 & 0.48 & 0.51 \\
$\mathrm{PC}_{3}$ & 0.13 & -0.21 & -0.22 & -0.07 & 0.01 & -0.06 & -0.36 & 0.81 & 0.14 & 0.12 & -0.18 & -0.19 \\
$\mathrm{PC}_{4}$ & 0.32 & -0.34 & -0.31 & -0.13 & -0.07 & -0.17 & -0.02 & -0.34 & 0.17 & 0.69 & 0.08 & 0.09 \\
$\mathrm{PC}_{5}$ & 0.04 & 0.06 & 0.00 & -0.12 & 0.00 & 0.06 & 0.81 & 0.44 & -0.11 & 0.23 & 0.18 & 0.20 \\
$\mathrm{PC}_{6}$ & -0.03 & -0.01 & 0.01 & 0.29 & 0.05 & -0.31 & 0.34 & -0.05 & 0.76 & -0.16 & -0.19 & -0.23 \\
$\mathrm{PC}_{7}{ }^{*}$ & -0.15 & -0.50 & -0.35 & 0.60 & 0.13 & 0.21 & 0.03 & 0.02 & -0.09 & -0.18 & 0.08 & 0.37 \\
$\mathrm{PC}_{8}$ & -0.59 & -0.24 & 0.06 & -0.34 & 0.42 & 0.40 & 0.01 & -0.06 & 0.24 & 0.19 & 0.07 & -0.19 \\
$\mathrm{PC}_{9}$ & 0.41 & -0.30 & 0.17 & -0.44 & 0.19 & 0.15 & 0.05 & -0.05 & 0.17 & -0.37 & -0.32 & 0.43 \\
$\mathrm{PC}_{10}$ & -0.22 & -0.36 & 0.70 & 0.20 & -0.21 & -0.20 & -0.03 & 0.08 & -0.12 & 0.29 & -0.29 & 0.14 \\
$\mathrm{PC}_{11}$ & -0.30 & 0.44 & -0.29 & 0.01 & 0.03 & 0.02 & -0.03 & -0.02 & 0.04 & 0.23 & -0.63 & 0.43 \\
$\mathrm{PC}_{12}$ & 0.00 & 0.00 & 0.00 & 0.00 & -0.74 & 0.60 & 0.00 & 0.00 & 0.30 & 0.00 & 0.00 & 0.00 \\
\hline
\end{tabular}

FL: fruit length (mm), FW: fruit width (mm), FT: fruit thickness (mm), FV: fruit volume (ml), FWE: fruit weight (g), FPW: fruit pulp weight (g), TSS: total soluble solids ( ${ }^{\circ}$ Brix), $\mathrm{pH}$ : hydrogen potential, SWE: seed weight (g), SL: seed length (mm), SW: seed width (mm) and ST: seed thickness (mm).

${ }^{*}$ There was no disposal suggestion in the seventh principal component, since the highest rate is susceptible to the discard of the ninth component.

has been inserted in the discard list, it deserves attention because it brings important information to the cajá tree genotype selection process, and because it is worth to be associated with other attributes such as pulp yield.

On the other hand, the current results suggest that the following variables may be kept: fruit width, pulp weight, $\mathrm{pH}$, seed length and seed thickness. These variables can be used in studies aiming at selecting genotype to develop breeding programs, to conserve species and to identify contrasting genotypes for promising crossings.

The Tocher grouping method and the principal component analysis met the similarity determination among genotypes after ten distinct groups were formed. When the principal component scores were compared to the producer groups, through the Tocher method algorithm, a certain similarity between analyses was noticed, because the group discriminations were similar.

The principal component analysis allowed the identification of redundant variables, i.e., those that had little influence on genotype discrimination. The redundant variable discards allowed the optimization of the original set, thus, after the discard, the data set was reviewed in order to check possible grouping differences.

The absorption presented by the first three principal components showed no significant changes and represented $87 \%$ of the total variation after seven variables were discarded. The Tocher method reduced the number of groups from ten to seven (Table 5).

After the variables were discarded, due to the Tocher analysis, $95 \%$ of the genotypes were concentrated in group IV; different from the previous analysis applied to group IV, that concentrated $76 \%$ of the individuals (Table 5). Groups VI and VII included the same genotype isolates found in groups IX and $\mathrm{X}$ in previous analysis; however, the descriptors did not migrate to the main groups. These genotypes were notice to integrate the last analyzed groups, with and without discard.

The MAR37 and NBA41 individuals were different from the others in both analyses, 
TABLE 5

Grouping of the 60 Spondia mombin genotypes through the Tocher grouping method, by using the mean Euclidean distance as genetic distance measure, based on the 05 most important morphological traits

\begin{tabular}{cl} 
Groups & \multicolumn{1}{c}{ Genotypes } \\
I & MAR32 MAR33 MAR31 MAR35 NBA48 NBA44 AFL16 MAR26 NBA45 NBA46 NBA43 AFL2 AFL9 \\
& AFL19 MAR23 MAR30 NBA42 AFL18 AFL14 AFL1 MAR28 AFL8 AFL17 NBA47 AFL6 AFL13 AFL20 \\
& AFL11 AFL3 MAR24 22 MAR40 MAR25 AFL12 NBA54 NBA56 NBA50 \\
II & MAR27 MAR36 MAR29 AFL7 NBA57 NBA60 NBA59 AFL4 AFL5 \\
III & NBA51 NBA53 NBA52 NBA55 AFL10 NBA49 \\
IV & MAR34 MAR39 MAR21 MAR38 NBA58 \\
V & AFL15 \\
VI & MAR37 \\
VII & NBA41 \\
\hline
\end{tabular}

with and without discard, just as it was found through the UPGMA method, which has presented higher divergence than the others.

\section{DISCUSSION}

The fruit length values were close to those found by Cassimiro, Macêdo and Menino (2009), who assessed cajá trees provided by the Active Germplasm Bank of Emepa-PB: the general average was equal to $34.7 \mathrm{~mm}$, which ranged from 29.5 to $42.0 \mathrm{~mm}$. The mean fruit mass was lower -8.69 - but very close to that found by Aldrigue (1988) and Bosco, Soares, Aguiar-Filho and Barros (2000) 10 and $9.5 \mathrm{~g}$, respectively. Pinto et al. (2003) in their study focused on characterizing cajá fruit tree genotypes in Bahia State, identified agroindustrial materials of interest for species enhancement and found mean pulp mass $6.11 \mathrm{~g}$, which is close to that found in the present study.

The fruit production for industrial purpose must emphasize fruits with high pulp yield, high sugar content and acidity; however, the lack of production technology is one of the main commercial exploitation barriers (Pinto et al., 2003). The $\mathrm{pH}$ also has great influence on food quality and safety, as it indicates the deterioration potential, which is attested by the developed acidity (Gava, 1978).

The traits that greatly contributed to the genetic variability of the studied genotypes were fruit width, pulp weight, $\mathrm{pH}$, and seed width and mass. Therefore, these traits were the most responsive to the genotype selection in the herein studied species.

The Tocher grouping method, which was commonly used in the first groups, focuses on a larger number of genotypes, as shown by in $S$. mombin, in the current study. This analysis type keeps homogeneity within the groups and heterogeneity among groups. Thus, the largest number of individuals in a given group indicates their great genetic similarity. Individuals framed in the last group presented greater divergence than those in the first group (Elias, Vidigal, Gonela, \& Vogt, 2007). In addition, this optimization technique groups the individuals and keeps the criterion used to maintain the intragroup distances often shorter than the intergroup ones (Cruz, Regazzi, \& Carneiro, 2004).

According to Capinan (2007), the use of the Tocher grouping method enabled assessing the variability among plants. It is clear in the present study, since the analyses have revealed genetic divergence among the assessed genotypes as in the studies by Viola, Barelli, Salomão, Santos and Ambrozio (2013), who used different Cagaita tree genotypes; and by Lente, Barelli, Ambrozio, Silva and Santos (2013), which assessed 28 Mangaba individuals.

The principal components of the first components associated with the highest eigenvalue showed the largest data variance, what assured their representativeness in the set of assessed 
variables (Castellen Ledo, Oliveira, MonteiroFilho, \& Danta, 2007). The results in the present study were similar to those found by Pinto et al. (2003) in their study about cajá tree genotypes, wherein the two first principal components explained $80.9 \%$ of the total variation. Godoy et al. (2007), in a study on the genetic diversity of passion fruit genotypes, found $69.07 \%$ total variation in the three principal components; such rate is lower than that found in the present study. Junior, Bruckner, Cantín, Sánchez and Cruz (2011) assessed the genetic divergence among 17 peach tree populations and found 80 $\%$ variation in the three principal components.

According to Alves et al. (2003), the interest in assessing the relative importance of traits lies on the possibility of withdrawing features of little contribution to the assessed material discrimination, which reduces labor cost, time and experimentation cost. According to Rosse and Fernandes (2002), this criterion is more efficient to identify less informative traits when a set of at least ten traits is taken into account.

There were genetic divergences among the analyzed genotypes. Individuals MAR37 and NBA41 were the most promising for crossings in future programs aiming at genetically enhancing the species and at domesticating it. These two individuals are stored in situ and available for research.

\section{ACKNOWLEDGMENT}

The authors thank FAPEMAT (Project: Conservação e uso de espécies vegetais nativas da região Amazônica com potencial econômico para região Norte do estado de Mato Grosso. Process n. 166159/2014) for its financial support. Bruna Mezzalira da Silva was granted with a Master's Degree scholarship by FAPEMAT/CAPES.

\section{RESUMEN}

Divergencia genética entre genotipos de Spondias mombin (Anacardiaceae) según caracteres morfológicos. Spondias mombin es un árbol nativo de la región amazónica; su explotación se produce de manera extractiva, siendo aún incipiente el cultivo de la especie. El objetivo de este estudio fue evaluar la divergencia genética entre genotipos de $S$. mombin y cuantificar la contribución relativa de 12 características morfológicas de frutos y semillas, para obtener datos que permitan investigaciones futuras relativas a la conservación y domesticación de la especie. Se evaluaron 60 genotipos; de cada uno se analizaron diez frutos. Los descriptores utilizados para la caracterización de los frutos fueron ocho: masa del fruto, peso de la pulpa, volumen, longitud, anchura, espesor, contenido total de sólidos solubles y $\mathrm{pH}$; los descriptores de semillas fueron cuatro: masa, longitud, anchura y espesor. Los datos se evaluaron por medio de componentes principales y agrupaciones obtenidas por métodos UPGMA y Tocher, de la matriz de disimilitud (distancia euclideana media) con ayuda del programa GENES. A través del análisis de los componentes principales, se verificó que los tres primeros componentes explican $83.63 \%$ de la variación acumulada. Las características que más contribuyen a la discriminación de los genotipos fueron: anchura del fruto, peso de la pulpa, $\mathrm{pH}$, longitud y espesor de semillas, y son las más significativas para la selección de genotipos de S. mombin. Las contribuciones más pequeñas a la diversidad se deben a: la masa del fruto, anchura de semilla, espesor, volumen y longitud del fruto, así como a la masa de las semillas y el contenido de sólidos solubles totales. Ambos métodos de agrupación, UPGMA y Tocher, revelaron que existe divergencia genética entre los genotipos analizados. Los genotipos 37 y 41 son los más divergentes respecto a los otros; por eso son ideales para programas de mejoramiento genético con miras a la domesticación de la especie.

Palabras clave: árboles frutales, selva amazónica, recursos genéticos, mejoramiento genético.

\section{REFERENCES}

Aldrigue, M. L. (1988). Caracterização física, química e físico-química do cajá (Spondias lutea L.). In Seminário Agropecuário do Acre, 1986, Rio Branco. Anais Brasília: Embrapa-UEPAE de Rio Branco, 323-327.

Alves, R. M., Garcia, A. A. F., Cruz, A. D., \& Figueira, A. (2003). Seleção de descritores botânico-agronômicos para caracterização de germoplasma de cupuaçuzeiro. Pesquisa Agropecuária Brasileira, 38, 807-818.

Borém, A. (2006). Aplicação dos marcadores moleculares no melhoramento de plantas. Marcadores Moleculares, Viçosa, UFV, 79-84.

Bosco, J., Soares, K. T., Aguiar-Filho, S. D., \& Barros, R. V. (2000). A cultura da cajazeira. João Pessoa, Brasil: EMEPA-PB.

Braga, F. M., Dos Santos, E. C., Junqueira, N. T. V., Sousa, A. A. T. C., Faleiro, F. G., Rezende, L. N., \& Junqueira, K. P. (2006). Enraizamento de estacas de três 
espécies silvestres de Passiflora. Revista Brasileira de Fruticultura, 28, 284-288.

Ministério da Agricultura, Pecuária e Abastecimento, Brasil. (2007). Cadeia produtiva de Frutas. Retrieved from <http://www.ibraf.org.br/x files/Documentos/Cadeia_Produtiva_de_Frutas_S\%C3\%A9rie Agroneg\% $\% \overline{\mathrm{C}} \%$ B3 3 cios $\mathrm{MAPA}$.pdf $>$

Capinan, G. C. S. (2007). Seleção de germoplasma de mangabeira (Hancornia speciosa Gomes) definidos por marcadores morfológicos e moleculares (Masters dissertation). Universidade Federal do Recôncavo da Bahia, Brasil.

Cassimiro, C. M., Macêdo, L. S., \& Menino, I. B. (2009). Avaliação de acessos de cajazeira (Spondias mombin) do Banco Ativo de Germoplasma da Emepa, PB. Tecnologia e Ciência Agropecuária, 3, 01-06.

Castellen, M. da S., Ledo, C. A. da S., Oliveira, E. J. de, Monteiro-Filho, L. S., \& Danta, J. L. L. (2007). Caracterização de acessos do banco ativo de germoplasma de mamão por meio de análise multivariada. Magistra, 19, 299-303.

Coelho, C. M. M., Coimbra, J. L. M., Souza, C. A., Bogo, A., \& Guidolin, A. F. (2007). Diversidade genética em acessos de feijão (Phaseolus vulgaris.L.). Ciência Rural, 37, 1241-1247.

Cruz, C. D. (2008). Programa Genes: aplicativo computacional em genética e estatística. Viçosa: Universidade Federal de Viçosa.

Cruz, C. D., Regazzi, A. J., \& Carneiro, P. C. S. (2004) Modelos biométricos aplicados ao melhoramento genético. Viçosa: Universidade Federal de Viçosa.

Elias, H. T., Vidigal, M. C. G., Gonela, A., \& Vogt, G. A. (2007). Variabilidade genética em germoplasma tradicional de feijão preto em Santa Catarina. Pesquisa Agropecuária Brasileira, 42, 1443-1449.

Gava, A. J. (1978). Princípios de tecnologia de alimentos. São Paulo, Brasil: Nobel Editora.

Godoy, R. C., Ledo C. A. S., Santos A. P., Matos, E. L. S., Lima A. A., \& Waszczynskyj, N. (2007). Diversidade genética entre acessos de maracujazeiroamarelo avaliada pelas características físico-químicas dos frutos. Revista Ceres, 54, 541-547.

International Plant Genetic Resources Institute (IPGRI) (1996). Descriptors for banana (Musa spp.). Rome, Italy, IPGRI.

Jolliffe, I. T. (1972). Discarding variables in a principal component analysis. I: Artificial data. Applied Statistics, 21, 60-173.

Junior, A. W., Bruckner, C. H., Cantín, C. M., Sánchez, M. A. M., \& Cruz, C. D. (2011) Divergência genética entre progênies de pessegueiro em
Zaragoza, Espanha. Revista Brasileira de Fruticultu$r a, 33(01), 3030-310$.

Khattree, R., \& Naik, D. N. (2000). Multivariate data reduction and discrimination with SAS software. USA: Sas Institute.

Lente, L. J., Barelli, M. A. A., Ambrozio, V. C., Silva, C. R., \& Santos, A. A. B. (2013). Caracterização Da Divergência Genética da Mangaba (Hancornia speciosa Gomes) Pelo Método de Agrupamento De Otimização De Tocher. Brasil: Universidade do Estado de Mato Grosso.

Martins, S. T., \& Melo, B. (2006). Característica do cajá. Retrieved from http://www.todafruta.com.br/todafruta/mostra_conteudo.asp

Pinto, W. da S., Dantas, A. C. V. L., Fonseca, A. A. O., Ledo, C. A. da S. L., Jesus, S. C. De, Calafrange, P. L. P., \& Andrade, E. M. (2003). Caracterização física, físico-química e química de frutos de genótipos de cajazeira. Pesquisa Agropecuária Brasilei$r a, 38,1059-1066$.

Rao, C. R. (1952). Advanced statistical methods in biometric research. New York, USA: Jonh Wiley \& Sons.

Rosse, L. N., \& Fernandes, J. S. C. (2002). Escolha de caracteres para o melhoramento genético em ervamate por meio de técnicas multivariadas. Ciência Florestal, 12, 21-27.

Schwartz, E., Fachinello, J. C., Barbieri, R. L., \& Silva, J. B. (2010). Avaliação de populações de Butia Capitata de Santa Vitória do Palmar. Revista Brasileira de Fruticultura, 32, 736-745.

Silva-Junior, J. F. D., Bezerra, J. E. F., Lederman, I. E., Alves, M. A., \& Neto, M. L. D. (2004). Collecting, ex situ conservation and characterization of "cajaumbu" (Spondias mombin x Spondias tuberosa) germplasm in Pernambuco State, Brazil. Genetic Resources and Crop Evolution, 51, 343-349.

Sneath, P. H., \& Sokal, R. R. (1973). Numerical taxonomy. The principles and practice of numerical classification. San Francisco, USA: W.H. Freeman.

Sokal, R. R., \& Rohlf, F. J. (1962). The comparison of dendrograms by objective methods. Taxon, 97, 33-40.

Vieira, J. (2007). Caracterização morfológica e molecular do banco de germoplasma de arroz irrigado (Oryza sativa L.) da Epagri (Doctoral dissertation). Universidade Federal de Santa Catarina, Brasil.

Viola, M. H., Barelli, M. A. A., Salomão, R. T., Santos, A. A. B., \& Ambrozio, V. C. (2013). Caracterização Da Divergência Genética da Cagaita (Eugenia dysenterica DC.) Pelo Método de Agrupamento De Otimização De Tocher. Brasil: Universidade do Estado de Mato Grosso. 